\title{
Differential Response of Two Almond Rootstocks to Chloride Salt Mixtures in the Growing Medium ${ }^{1}$
}

\author{
A. Zrig ${ }^{a}$, T. Tounekti ${ }^{b, d}$, H. BenMohamed ${ }^{c}$, H. Abdelgawad ${ }^{d}$, A. M. Vadel ${ }^{a}$, D. Valero ${ }^{e}$, and H. Khemira ${ }^{b}$ \\ ${ }^{a}$ Unité de Recherche Biodiversité et Valorisation des Bioresources en Zones Arides, Faculté des Sciences de Gabés, \\ University of Gabes, City Erriadh, Tunisia \\ ${ }^{b}$ Centre for Environmental Research and Studies (CERS), Jazan University, Jazan, Kingdom of Saudi Arabia \\ ${ }^{c}$ Laboratoire d'Horticulture, Institut National de Recherche Agronomique de Tunisie (INRAT), Ariana, Tunisia \\ ${ }^{d}$ Laboratory for Molecular Plant Physiology and Biotechnology, Department of Biology, \\ University of Antwerp, Antwerp, Belgium \\ ${ }^{e}$ Department of Food Technology, University Miguel Hernández, Orihuela, Alicante, Spain \\ e-mail: habibkhemira@yahoo.com \\ Received November 24, 2014
}

\begin{abstract}
It was examined how essential cations, $\mathrm{Ca}^{2+}$ and $\mathrm{K}^{+}$, can mitigate the toxic effects of $\mathrm{NaCl}$ on two different almond species (Prunus amygdalus Batsch) rootstocks, Garnem (GN15) and Bitter Almond. The tree growth parameters (water potential $\left(\Psi_{\mathrm{w}}\right)$, gas exchange, nutrient uptake) and leaf chlorophyll (Chl) content were measured in control and $\mathrm{NaCl}$-treated plants with or without $\mathrm{KCl}$ or $\mathrm{CaCl}_{2}$ supplements. The addition of $\mathrm{CaCl}_{2}$ and $\mathrm{KCl}$ to Bitter Almond trees reduced their dry weight, shoot growth and leaf number although net photosynthetic assimilation rate $(A)$ was not affected. These results indicated that changing of photo-assimilates flux to proline and/or soluble sugars synthesis may help to increase leaf $\Psi_{\mathrm{w}}$. The Garnem trees also did not respond to the $\mathrm{CaCl}_{2}$ and $\mathrm{KCl}$ addition indicating that the plants are already getting enough of these two cations $\left(\mathrm{Ca}^{2+}\right.$ and $\left.\mathrm{K}^{+}\right)$. In both rootstocks, $\mathrm{NaCl}$ in the medium reduced growth attributes, $\Psi_{\mathrm{w}}$, $A$, stomatal conductance $\left(g_{\mathrm{s}}\right)$, and leaf $\mathrm{Chl}$ content. When $\mathrm{CaCl}_{2}$ and $\mathrm{KCl}$ fertilizers were added together with $\mathrm{NaCl}$ to Bitter Almond trees, leaf $\mathrm{K}^{+}$and $\mathrm{Ca}^{2+}$ contents increased while $\mathrm{Na}^{+}$and $\mathrm{Cl}^{-}$decreased leading to higher $\mathrm{Ca} / \mathrm{Na}$ and $\mathrm{K} / \mathrm{Na}$ ratios, but shoot growth was not improved and even declined compared to $\mathrm{NaCl}-$ treated trees. It appears that the addition of salts further aggravated osmotic stress as indicated by the accumulation of proline and soluble sugars in leaf tissues. The addition of $\mathrm{KCl}$ or $\mathrm{CaCl}_{2}$ to NaCl-treated GN15 trees did not increase $A$, leaf $\Psi_{\mathrm{w}}$, and shoot growth but improved ionic balances as indicated by higher $\mathrm{Ca} / \mathrm{Na}$ and $\mathrm{K} / \mathrm{Na}$ ratios. The reduction in $A$ was mainly due to non-stomatal limitations in GN15, possibly due to the degradation of Chl $a$, unlike Bitter Almond, for which the reduction of $A$ was due to stomata closure. The improvement in ionic balances and water status of Bitter Almond trees in response to addition of $\mathrm{KCl}$ or $\mathrm{CaCl}_{2}$ was apparently offset by a high sensitivity to $\mathrm{Cl}^{-}$; therefore, no-chloride salts should be the preferred forms of fertilizers for this rootstock. Both rootstocks were sensitive to soil salinity and cation supplements were of limited value in mitigating the effect of excessive salt concentrations.
\end{abstract}

Keywords: Prunus amygdalus, Garnem, Bitter Almond, rootstocks, proline, soluble sugars, $\mathrm{Ca} / \mathrm{Na}, \mathrm{K} / \mathrm{Na}$, cation nutrition, salinity

DOI: $10.1134 / \mathrm{S} 1021443716010192$

\section{INTRODUCTION}

The problem of salinity is especially serious in arid areas due to excessive evaporation and the scarcity of good quality water for irrigation. The term salinity refers to the total concentration of the major dissolved inorganic ions, $\mathrm{Na}^{+}, \mathrm{Ca}^{2+}, \mathrm{Mg}^{2+}, \mathrm{K}^{+}, \mathrm{HCO}^{3-}, \mathrm{SO}_{4}^{2-}$ and $\mathrm{Cl}^{-}$in the soil solution [1]. High salt levels lead to

\footnotetext{
${ }^{1}$ The article is published in the original.

Abbreviations: $A-$ net photosynthetic assimilation rate, $\mathrm{Chl}-$ chlorophyll, EC-electrical conductivity, $E$ - transpiration rate, $g_{\mathrm{s}}$ - stomatal conductance, iWUE-instantaneous water use efficiency, TSS - total soluble sugars, $\Psi_{\mathrm{w}}$-leaf water potential.
}

osmotic stress coupled with ionic imbalances caused by the increased uptake of toxic ions such as $\mathrm{Na}^{+}$and $\mathrm{Cl}^{-}$[1]. The salt stress has also an adverse effect on mineral $\mathrm{Ca}^{2+}$ and $\mathrm{K}^{+}$homeostasis [1, 2]. An excess or deficiency of the major elements in plant's tissues may cause disorders with respect to nutrient availability, uptake, transport or partitioning within the plant. Thus, there may be a need to use fertilizers to alleviate the harmful effects of excessive soil salinity. Indeed, $\mathrm{Ca}^{2+}$ is known to displace $\mathrm{Na}^{+}$from soil exchange colloids and render it easier to be leached down the soil profile with drainage. Furthermore, maintaining enough supply of $\mathrm{Ca}^{2+}$ and $\mathrm{K}^{+}$in saline soil solution is 
Table 1. Nutrient solution composition and electrical conductivity

\begin{tabular}{l|l|c}
\hline \multicolumn{1}{c|}{ Treatment } & \multicolumn{1}{|c}{ Irrigation solution composition } & EC, dS/m \\
\hline Control & Basal nutriment solution $(\mathrm{C})$ & 2.97 \\
$\mathrm{CaCl}_{2}$ & $\mathrm{C}+8 \mathrm{mM} \mathrm{CaCl}_{2}$ & 4.77 \\
$\mathrm{KCl}$ & $\mathrm{C}+10 \mathrm{mM} \mathrm{KCl}$ & 4.17 \\
$\mathrm{NaCl}$ & $\mathrm{C}+75 \mathrm{mM} \mathrm{NaCl}$ & 9.95 \\
$\mathrm{NaCl}+\mathrm{CaCl}_{2}$ & $\mathrm{C}+75 \mathrm{mM} \mathrm{NaCl}+8 \mathrm{mM} \mathrm{CaCl}_{2}$ & 11.77 \\
$\mathrm{NaCl}+\mathrm{KCl}$ & $\mathrm{C}+75 \mathrm{mM} \mathrm{NaCl}+10 \mathrm{mM} \mathrm{KCl}$ & 11.17 \\
\hline
\end{tabular}

a key factor in controlling specific ion toxicities, especially in crops prone to $\mathrm{Na}^{+}$and $\mathrm{Cl}^{-}$toxicity [1]. Potassium and $\mathrm{Ca}^{2+}$ are essential for plants; $\mathrm{Ca}^{2+}$ plays integrity role in cell membrane integrity, signal transduction and the control of enzyme activity [3], while $\mathrm{K}^{+}$is involved in a number of metabolic processes such as photosynthesis, enzyme activation, protein synthesis, osmotic adjustment, and as a counter ion to both inorganic anions and organic biopolymers [3]. $\mathrm{K}^{+}$ uptake and transport in plants are strongly depressed in the presence of $\mathrm{Na}^{+}$and enhanced by $\mathrm{Ca}^{2+}$ supplements.

Most fruit trees are considered sensitive to soluble salts especially $\mathrm{Cl}^{-}$. Irrigation with saline water may greatly reduce their yield [4]. The earliest symptoms of ion toxicity are typically caused by $\mathrm{Cl}^{-}$excessive contents in the leaves while $\mathrm{Na}^{+}$tends to be retained in the roots, trunk, and branches, so its content in the leaves remains relatively low for several years [4]. Therefore, the role of the rootstock is crucial in determining the tree performance under saline conditions [5].

In the Mediterranean region, Garnem (Garfi Almond $\times$ Nemared) peach hybrid with reddish leaves, has gained popularity among nurserymen for its tolerance of drought and calcareous soils [6]. In many countries including Tunisia, Bitter Almond (BA) is also still widely used as a rootstock for almond and peach because of its deep root system and tolerance to drought [7].

The present study was set up to evaluate how increased essential cations supply may mitigate the harmful effects of $\mathrm{NaCl}$ salinity on two distinct widely-planted almond rootstocks.

\section{MATERIALS AND METHODS}

Plant material and culture. One-year-old rooted cuttings of Garnem (GN15) and seedlings of Bitter Almond (Prunus amygdalus Batsch) were grown in 4-L plastic pots containing desert dune sand under a non-heated lath house (average PPFD of $\left.1100 \mu \mathrm{mol} /\left(\mathrm{m}^{2} \mathrm{~s}\right)\right)$. The plants were obtained from a commercial nursery then cultivated during two months (June and July) with daily maximum air temperatures ranging between $27^{\circ} \mathrm{C}$ and $31^{\circ} \mathrm{C}$, while relative air humidity ranged between 49 and $60 \%$. Dur- ing the first 3 weeks of cultivation, the plants received a complete nutrient solution prepared with deionized water to which salts were added so to obtain an electrical conductivity (EC) of $2.77 \mathrm{dS} / \mathrm{m}$ and an initial total ion concentration of $4.5 \mathrm{mM}$ consisting of $1.8 \mathrm{mM} \quad \mathrm{KNO}_{3}, \quad 0.64 \mathrm{mM} \quad \mathrm{KH}_{2} \mathrm{PO}_{4}, \quad 1.0 \mathrm{mM}$ $\mathrm{Ca}\left(\mathrm{NO}_{3}\right)_{2}, 0.35 \mathrm{mM} \mathrm{MgSO}, 0.03 \mathrm{mM}$ Fe-EDTA,

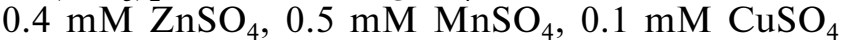
and $0.023 \mathrm{mM} \mathrm{H}_{3} \mathrm{BO}_{3}$.

After this initial acclimation phase, 24 plants of each rootstock were selected for uniformity in size and growth. Each set of four trees of each stock was watered with one of the following six solutions (treatments): i-control (basic nutrient solution), ii-control $+10 \mathrm{mM} \mathrm{KCl}$, iii-control $+8 \mathrm{mM} \mathrm{CaCl}_{2}$, ivsalt stress (basic nutrient solution $+75 \mathrm{mM} \mathrm{NaCl}$ ), $\mathrm{v}$-salt stress $+10 \mathrm{mM} \mathrm{KCl}$, and vi-salt stress + $10 \mathrm{mM} \mathrm{CaCl}$. The electrical conductivity (EC) of each solution is given in Table 1. The surface of pots was covered with black plastic to minimize evaporation and to prevent algal growth. The experimental design was a completely randomized block with four replicates (each pot being a replicate).

The plants were harvested after 4 weeks of imposing the treatments. The leaves of each plant were collected and divided into two batches, one was immediately frozen in liquid nitrogen then stored at $-80^{\circ} \mathrm{C}$ for further biochemical analyses, the other was briefly washed free of dust in de-ionized water, dried at $80^{\circ} \mathrm{C}$ in a forced-air oven for $48 \mathrm{~h}$ and ground into a fine powder to pass through a 40 -mesh screen for mineral analyses.

Plant growth, water potential, ion content, and gas exchange measurements. The total leaf number, tree dry weight, and shoot length were used to estimate plant growth. The predawn water potential $\left(\Psi_{\mathrm{w}}\right)$ of shoots was measured with a pressure chamber (Soil Moisture Equipment Co., United States). The net photosynthetic assimilation rate $(A)$, transpiration rate $(E)$, and stomatal conductance $\left(g_{s}\right)$ were determined using an LCpro+ portable photosynthesis system (ADC, BioScientific, Ltd, United Kingdom). The instantaneous water use efficiency (iWUE) was calculated as the ratio between $A$ and $E$ [8].

For determination of mineral contents, they were extracted from dried leaves $(1 \mathrm{~g})$ with $20 \mathrm{~mL}$ of $0.1 \mathrm{M}$ 
$\mathrm{HNO}_{3}$. Then after filtration, the $\mathrm{K}^{+}, \mathrm{Na}^{+}$, and $\mathrm{Ca}^{2+}$ contents were determined with an atomic absorption spectrometer (Avanta, GBC, Australia). The $\mathrm{Cl}^{-}$content was determined with chloride analyzer (Corning M926 chloride analyzer, Sherwood Scientific, United Kingdom).

Determination of proline, soluble sugars, and chlorophyll contents. The frozen leaves $(0.2 \mathrm{~g})$ were ground to a fine powder in a pre-cooled mortar with liquid nitrogen, homogenized with $5 \mathrm{~mL}$ of $3 \%$ aqueous sulfosalicylic acid and centrifuged at $8000 \mathrm{~g}$ for $15 \mathrm{~min}$. Then $2 \mathrm{~mL}$ of acid-ninhydrin and $2 \mathrm{~mL}$ of glacial acetic acid were added to $2 \mathrm{~mL}$ of the homogenate in a test tube. The mixture was then incubated at $100^{\circ} \mathrm{C}$ for $1 \mathrm{~h}$, after which the reaction was stopped by placing the test tube in an ice bath. Then $4 \mathrm{~mL}$ of toluene were added to each test tube and vortexed for $20 \mathrm{~s}$. The absorbance at $520 \mathrm{~nm}$ of the organic toluene phase containing the chromophore was used to quantify the amount of proline as described by Bates et al. [9].

The total soluble sugars in leaf tissue were determined according to the method of Robyt and White [10]. The leaves powder $(100 \mathrm{mg})$ was extracted by $80 \%$ (v/v) methanol heated to $70^{\circ} \mathrm{C}$ in a water bath. The extract was then centrifuged at $5000 \mathrm{~g}$ for $10 \mathrm{~min}$. The supernatant was used for the estimation of soluble sugars contents. The reaction mixture consisted of $1 \mathrm{~mL} \mathrm{5 \%}$ phenol and $5 \mathrm{~mL} \mathrm{98 \%} \mathrm{sulphuric} \mathrm{acid.} \mathrm{After}$ the extract had been cooled, its absorbance was determined at $490 \mathrm{~nm}$ using D-glucose as standard [10].

The leaf chlorophylls (Chl) were extracted with acetone $(80 \%, \mathrm{v} / \mathrm{v})$ as described by Arnon [11]. The absorbance of the extract was read at 647 and $664 \mathrm{~nm}$ with a spectrophotometer.

The Chl contents were calculated as follows:

Chl $a(\mathrm{mg} / \mathrm{g}$ fr wt $)=\left[12.7 \times\left(A_{664}\right)-2.69 \times\left(A_{647}\right)\right]$,

$\mathrm{Chl} b(\mathrm{mg} / \mathrm{g}$ fr wt $)=\left[22.9 \times\left(A_{647}\right)-4.69 \times\left(A_{664}\right)\right]$.

Statistical analyses. The variance of data was analyzed with the GLM procedure of SAS software (SAS Institute, United States) [12] for a Randomized Complete Block design with four replicates. Where applicable, means were separated by Duncan's test $(P \leq 0.05)$.

\section{RESULTS \\ Effects of $\mathrm{NaCl}$ and Ionic Interactions on Plant Growth and Cation Contents}

The addition of $\mathrm{CaCl}_{2}$ and $\mathrm{KCl}$ to control plants (plants which did not receive additional $\mathrm{NaCl}$ ) of Bitter Almond reduced their growth attributes (Fig. 1). Similarly, the addition of $\mathrm{NaCl}$ alone to the medium reduced tree dry weight, leaf number, and shoot length. For Bitter Almond trees fed additional $\mathrm{NaCl}$, the addition of $\mathrm{CaCl}_{2}$ or $\mathrm{KCl}$ further reduced leaf number by 51 and $36 \%$, respectively, compared to the trees which received $\mathrm{NaCl}$ alone. Tree dry weight and shoot extension were further reduced (compared to

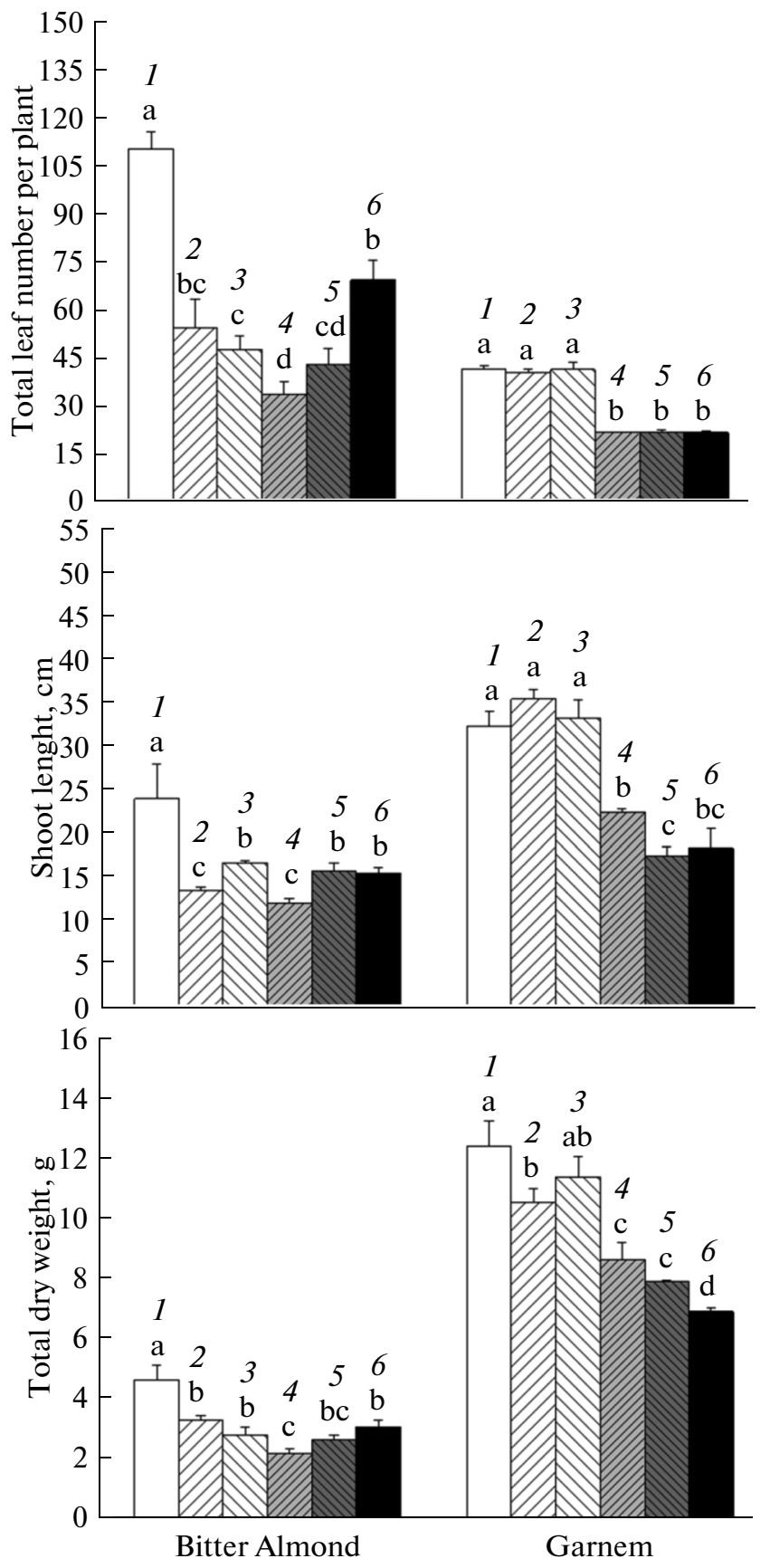

Fig. 1. Total leaf number, shoot length and dry weight of two almond rootstocks grown in a medium without $\mathrm{NaCl}$ (control), with $\mathrm{NaCl}$, or containing $\mathrm{KCl}$ or $\mathrm{CaCl}_{2}$ alone or together with $\mathrm{NaCl}$. 1-control; 2-8 $\mathrm{mM} \mathrm{CaCl}_{2}$; $3-10 \mathrm{mM} \mathrm{KCl} ; 4-75 \mathrm{mM} \mathrm{NaCl}+8 \mathrm{mM} \mathrm{CaCl}_{2} ; 5-$ $75 \mathrm{mM} \mathrm{NaCl}+10 \mathrm{mM} \mathrm{KCl} ; 6-75 \mathrm{mM} \mathrm{NaCl}$. Each point represents the mean $( \pm S E)$ of four replicates, values marked by different letters are significantly different at $P<0.05$.

those of the trees which received $\mathrm{NaCl}$ alone) by the addition of $\mathrm{CaCl}_{2}$ but not $\mathrm{KCl}$. Some leaves became scorched on the margins then fell off.

The Garnem trees did not respond to the addition of $\mathrm{CaCl}_{2}$ and $\mathrm{KCl}$ (Fig. 1). The leaf number and shoot 


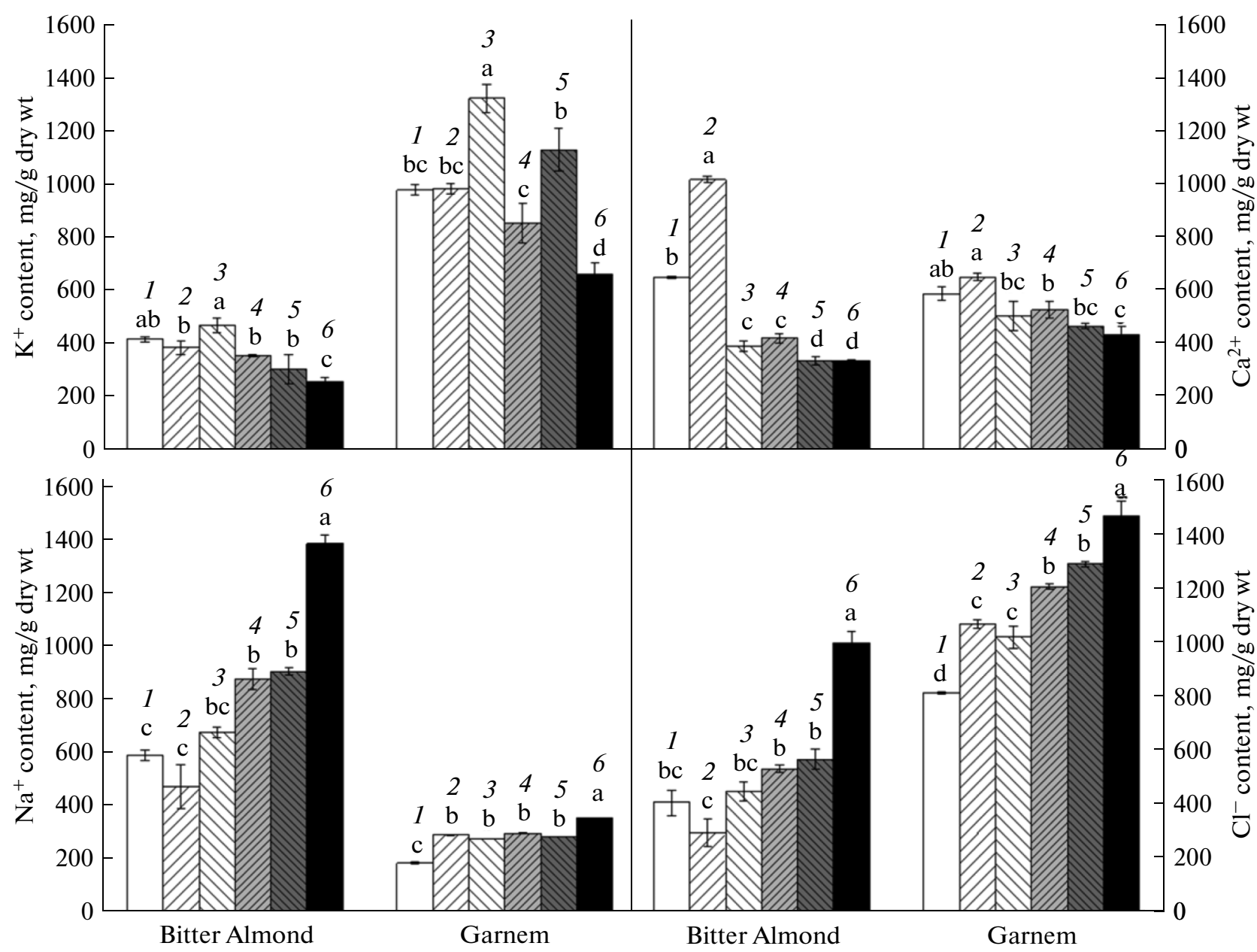

Fig. 2. Contents of $\mathrm{K}^{+}, \mathrm{Ca}^{2+}, \mathrm{Na}^{+}$, and $\mathrm{Cl}^{-}$in the leaves of two almond rootstocks grown in a medium without $\mathrm{NaCl}$ (control), with $\mathrm{NaCl}$, or containing $\mathrm{KCl}$ or $\mathrm{CaCl}_{2}$ alone or together with $\mathrm{NaCl}$. 1 -control; 2-8 $\mathrm{mM} \mathrm{CaCl} 2 ; 3-10 \mathrm{mM} \mathrm{KCl} ; 4-$ $75 \mathrm{mM} \mathrm{NaCl}+8 \mathrm{mM} \mathrm{CaCl}_{2} ; 5-75 \mathrm{mM} \mathrm{NaCl}+10 \mathrm{mM} \mathrm{KCl} ; 6-75 \mathrm{mM} \mathrm{NaCl}$. Each point represents the mean ( $\left.\pm \mathrm{SE}\right)$ of four replicates, values marked by different letters are significantly different at $P<0.05$.

length did not improve after fertilization with $\mathrm{CaCl}_{2}$ and $\mathrm{KCl}$; to the contrary, tree dry weight was even slightly lower. Furthermore, when $\mathrm{NaCl}$ was added alone, these parameters were $50 \%$ reduced. The addition of $\mathrm{CaCl}_{2}$ or $\mathrm{KCl}$ did not reverse this reduction in shoot growth and leaf number but increased tree dry weight.

The addition of $\mathrm{CaCl}_{2}$ to Bitter Almond trees increased leaf $\mathrm{Ca}^{2+}$ content by $62 \%$ compared to control plants but had no effect on $\mathrm{K}^{+}$content (Fig. 2). On the contrary, the addition of $\mathrm{KCl}$ to these plants decreased leaf $\mathrm{Ca}^{2+}$ content by $38 \%$ but had no significant effect on $\mathrm{K}^{+}$content. The addition of $\mathrm{NaCl}$ alone to the base solution increased considerably leaf $\mathrm{Na}^{+}$and $\mathrm{Cl}^{-}$content and suppressed $\mathrm{K}^{+}$and $\mathrm{Ca}^{2+}$ contents leading to large reductions in $\mathrm{Ca} / \mathrm{Na}$ and $\mathrm{K} / \mathrm{Na}$ ratios (Table 2). When $\mathrm{NaCl}$-treated Bitter Almond trees were fertilized with $\mathrm{CaCl}_{2}$, leaf $\mathrm{Na}^{+}$and $\mathrm{Cl}^{-}$contents significantly decreased while leaf $\mathrm{K}^{+}$and $\mathrm{Ca}^{2+}$ contents and $\mathrm{Ca} / \mathrm{Na}$ and $\mathrm{K} / \mathrm{Na}$ ratios increased.
The addition of $\mathrm{CaCl}_{2}$ to $\mathrm{GN} 15$ trees had no effect on leaf $\mathrm{Ca}^{2+}$ and $\mathrm{K}^{+}$contents but increased the content of $\mathrm{Cl}^{-}$and reduced $\mathrm{Ca} / \mathrm{Na}$ and $\mathrm{K} / \mathrm{Na}$ ratios compared to control plants (Fig. 2; Table 2). When $\mathrm{KCl}$ was added alone, it increased leaf $\mathrm{K}^{+}$content by $33 \%$ but reduced $\mathrm{Ca}^{2+}$ content; $\mathrm{Ca} / \mathrm{Na}$ and $\mathrm{K} / \mathrm{Na}$ ratios were also lower. The addition of $\mathrm{NaCl}$ alone to the base solution increased leaf $\mathrm{Na}^{+}$and $\mathrm{Cl}^{-}$content by 75 and $82 \%$, respectively, while it reduced the contents of $\mathrm{Ca}^{2+}$ and $\mathrm{K}^{+}$by 28 and $37 \%$, respectively, leading to large reductions in $\mathrm{Ca} / \mathrm{Na}$ and $\mathrm{K} / \mathrm{Na}$ ratios. Furthermore, increasing the supply of calcium to NaCl-treated trees slightly increased leaf $\mathrm{Ca}^{2+}$ and $\mathrm{K}^{+}$contents and suppressed $\mathrm{Na}^{+}$and $\mathrm{Cl}^{-}$contents. Likewise, the addition of $\mathrm{KCl}$ to such trees led to large increase in $\mathrm{K}^{+}$content and decrease in $\mathrm{Na}^{+}$and $\mathrm{Cl}^{-}$contents compared to $\mathrm{NaCl}$-fed plants. Fertilization significantly increased $\mathrm{Ca} / \mathrm{Na}$ and $\mathrm{K} / \mathrm{Na}$ ratios (Table 2). Regardless of treatments, Garnem leaves always had more $\mathrm{Cl}^{-}$than $\mathrm{Na}^{+}$ while Bitter Almond leaves had more $\mathrm{Na}^{+}$than $\mathrm{Cl}^{-}$. 
Table 2. $\mathrm{K} / \mathrm{Na}$ and $\mathrm{Ca} / \mathrm{Na}$ ratios in the leaves of Bitter Almond and GN15 rootstocks exposed to different combinations of chloride salts

\begin{tabular}{|c|c|c|c|c|c|c|}
\hline Variety & Control (C) & $\mathrm{C}+\mathrm{CaCl}_{2}$ & $\mathrm{C}+\mathrm{KCl}$ & $\mathrm{NaCl}+\mathrm{CaCl}_{2}$ & $\mathrm{NaCl}+\mathrm{KCl}$ & $\mathrm{NaCl}$ \\
\hline \multicolumn{7}{|c|}{$\mathrm{K} / \mathrm{Na}$} \\
\hline Bitter Almond & $1.2^{\mathrm{a}}$ & $1.4^{\mathrm{a}}$ & $1.2^{\mathrm{a}}$ & $0.7^{\mathrm{b}}$ & $0.6^{\mathrm{b}}$ & $0.3^{\mathrm{c}}$ \\
\hline GN15 & $8.8^{\mathrm{a}}$ & $5.7^{\mathrm{bc}}$ & $8.0^{\mathrm{a}}$ & $4.8^{\mathrm{c}}$ & $6.7^{\mathrm{b}}$ & $3.2^{\mathrm{d}}$ \\
\hline \multicolumn{7}{|c|}{$\mathrm{Ca} / \mathrm{Na}$} \\
\hline Bitter Almond & $0.9^{\mathrm{b}}$ & $1.9^{\mathrm{a}}$ & $0.5^{\mathrm{c}}$ & $0.4^{\mathrm{c}}$ & $0.3^{\mathrm{cd}}$ & $0.2^{\mathrm{d}}$ \\
\hline GN15 & $2.7^{\mathrm{a}}$ & $1.9^{\mathrm{b}}$ & $1.6^{\mathrm{bc}}$ & $1.5^{\mathrm{bc}}$ & $1.4^{\mathrm{c}}$ & $1.1^{\mathrm{d}}$ \\
\hline
\end{tabular}

Each point represents the mean of four replicates; mean separation within rows by Duncan's Multiple Range Test $P<0.05$. Different letters means significance at $P<0.05$.

\section{Effects of $\mathrm{NaCl}$ and Ionic Interactions on Gas Exchange and Water Status}

Increasing $\mathrm{Ca}^{2+}$ supply to control trees of BA did not improve their $A$ but increased their $g_{\mathrm{s}}$ and $E$ considerably (Fig. 3). Similarly, adding $\mathrm{KCl}$ to the growing medium had no effect on $A$ and $E$ but reduced $g_{s}$. The addition of $\mathrm{NaCl}$ reduced all three parameters by more than $50 \%$ compared to control values. Similarly, adding of $\mathrm{CaCl}_{2}$ to $\mathrm{NaCl}$-treated trees further reduced their $A, g_{\mathrm{s}}$, and $E$, whereas $\mathrm{KCl}$ did not affect $A$ and $E$ but reduced $g_{\mathrm{s}}$. The $A / g_{\mathrm{s}}$ ratio increased by the addition of salts to the nutrient solution.

Adding of $\mathrm{CaCl}_{2}$ to $\mathrm{GN} 15$ control trees increased their $A$ and $g_{\mathrm{s}}$ but did not affect $E$ (Fig. 3). On the contrary, adding of $\mathrm{KCl}$ to the growing medium had no effect on $A$ and $g_{\mathrm{s}}$ but reduced $E$. The addition of $\mathrm{NaCl}$ alone reduced all three parameters. The $\mathrm{CaCl}_{2}$ or $\mathrm{KCl}$ adding to $\mathrm{NaCl}$-treated trees did not affect their $A$ but increased $g_{\mathrm{s}}$ and reduced $E$. The $A / g_{\mathrm{s}}$ ratio was reduced by the addition of salts to the nutrient solution.

Bitter Almond leaf $\Psi_{w}$ was increased by the $\mathrm{CaCl}_{2}$ addition but was unchanged by $\mathrm{KCl}$ (Fig. 3). On the contrary, it was reduced by more than $80 \%$ by $\mathrm{NaCl}$. The $\mathrm{CaCl}_{2}$ or $\mathrm{KCl}$ adding to $\mathrm{NaCl}$-treated trees increased their leaf $\Psi_{\mathrm{w}}$. All combinations of supplemental chloride salts except $\mathrm{KCl}$ improved water use efficiency (iWUE) of Bitter Almond plants compared to the control. All combinations of supplemental chloride salts reduced leaf $\Psi_{\mathrm{w}}$ of GN15 plants. Leaf $\Psi_{\mathrm{w}}$ of NaCltreated GN15 trees was further reduced by the addition of $\mathrm{CaCl}_{2}$ or $\mathrm{KCl}$. Adding $\mathrm{CaCl}_{2}$ or $\mathrm{KCl}$ to control and $\mathrm{NaCl}$-treated trees slightly improved their iWUE.

\section{Effects of $\mathrm{NaCl}$ and Ionic Interactions on Chlorophyll Content}

The addition of $\mathrm{CaCl}_{2}, \mathrm{KCl}$ or $\mathrm{NaCl}$ to Bitter Almond trees decreased leaf Chl $(a+b)$ and Chl $a$ contents but increased the content of Chl $b$ (Fig. 4). However, when $\mathrm{CaCl}_{2}$ was added together with $\mathrm{NaCl}$, Chl $(a+b)$ content increased considerably mainly as a result of more Chl $b$ content. Content of Chl $a$ was suppressed with $\mathrm{Chl} a / b$ ratio. In contrast, when $\mathrm{KCl}$ was added to NaCl-treated Bitter Almond trees, con- tents of Chl $(a+b), \mathrm{Chl} a, \mathrm{Chl} b$ decreased. The ratio Chl $a / b$ was not affected.

The addition of $\mathrm{CaCl}_{2}$ or $\mathrm{KCl}$ alone to the growing medium of GN15 trees increased leaf Chl $(a+b)$ content by 23 and $22 \%$, respectively, as compared to control plants (Fig. 4). Similarly, fertilization increased $\mathrm{Chl} a$ but not Chl $b$ contents. $\mathrm{CaCl}_{2}$ reduced $\mathrm{Chl} a / b$ ratio while $\mathrm{KCl}$ had no effect. The $\mathrm{NaCl}$ in the culture medium did not affect total $\mathrm{Chl}$ content but increased Chl $a$ and reduced Chl $b$ content resulting in a high increase in the ratio Chl $a / b$. Likewise, the additional supply of $\mathrm{CaCl}_{2}$ to $\mathrm{NaCl}$-treated trees did not affect total Chl and Chl $a$ contents but increased $\mathrm{Chl} b$ content resulting in a lower $\mathrm{Chl} a / b$ ratio compared to $\mathrm{NaCl}$-treated trees. The addition of $\mathrm{KCl}$ to $\mathrm{NaCl}-$ treated trees largely reduced total $\mathrm{Chl}$ and $\mathrm{Chl} a$ contents but increased Chl $b$ content resulting in a dramatically lower $\mathrm{Chl} a / b$ ratio compared to $\mathrm{NaCl}-$ treated trees.

\section{Effects of $\mathrm{NaCl}$ and Ionic Interactions on Proline and Total Soluble Sugar Contents}

The proline content in Bitter Almond leaves increased more than two folds when $\mathrm{CaCl}_{2}$ was added to the growing medium of control and $\mathrm{NaCl}$-treated plants (Fig. 5). On the contrary, it decreased when $\mathrm{KCl}$ was added instead of $\mathrm{CaCl}_{2}$. The addition of $\mathrm{NaCl}$ or $(\mathrm{NaCl}+\mathrm{KCl})$ did not change leaf proline content. In the $\mathrm{GN} 15$ trees, the addition of $\mathrm{CaCl}_{2}$ or $\mathrm{KCl}$ alone had no significant effect on proline content. The addition of $\mathrm{NaCl}$ increased proline content more than 2 fold. The addition of $\mathrm{CaCl}_{2}$ or $\mathrm{KCl}$ reduced proline content back to control level.

The addition of $\mathrm{CaCl}_{2}$ increased the content of total soluble sugars (TSS) in the leaves of Bitter Almond rootstock whereas $\mathrm{KCl}$ and $\mathrm{NaCl}$ did not (Fig. 5). The addition of $\mathrm{CaCl}_{2}$ or $\mathrm{KCl}$ to $\mathrm{NaCl}$-treated plants largely increased TSS content. In the case of GN15, all combinations of supplemental chloride salts except $(\mathrm{KCl}+$ $\mathrm{NaCl}$ ) did not change the content of leaf TSS. The latter treatment reduced TSS content by $84 \%$ compared to its level in $\mathrm{NaCl}$-treated trees. 


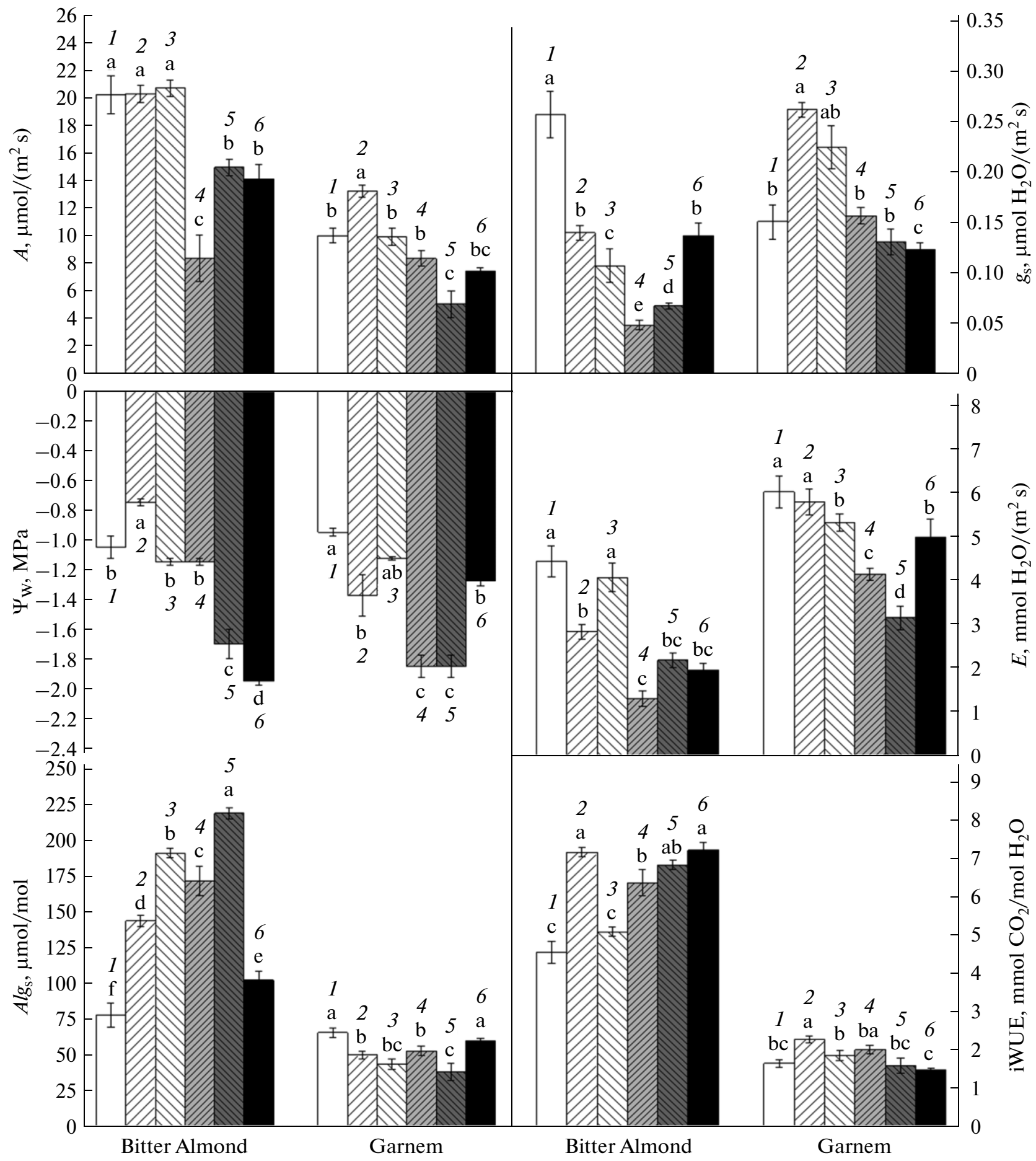

Fig. 3. Net photosynthesis $(A)$, stomatal conductance $\left(g_{\mathrm{s}}\right)$, transpiration rate $(E)$, leaf water potential $\left(\Psi_{\mathrm{w}}\right), A / g_{\mathrm{s}}$, and instantaneous water use efficiencies (iWUE $=A / E$ ) in the leaves of two almond rootstocks grown in a medium without $\mathrm{NaCl}$ (control), with $\mathrm{NaCl}$, or containing $\mathrm{KCl}$ or $\mathrm{CaCl}_{2}$ alone or together with $\mathrm{NaCl}$. 1 -control; $2-8 \mathrm{mM} \mathrm{CaCl}_{2} ; 3-10 \mathrm{mM} \mathrm{KCl} ; 4-75 \mathrm{mM}$ $\mathrm{NaCl}+8 \mathrm{mM} \mathrm{CaCl}_{2} ; 5-75 \mathrm{mM} \mathrm{NaCl}+10 \mathrm{mM} \mathrm{KCl} ; 6-75 \mathrm{mM} \mathrm{NaCl}$. Each point represents the mean ( $\left.\pm \mathrm{SE}\right)$ of four replicates, values marked by different letters are significantly different at $P<0.05$.

\section{DISCUSSION}

The present study tested the effect of increased $\mathrm{Ca}^{2+}$ and $\mathrm{K}^{+}$concentrations in the culture medium on the response of two almond rootstocks to $\mathrm{NaCl}$ stress.
The logic behind the experiment is the common assumption that increasing soil $\mathrm{Ca}^{2+}$ and $\mathrm{K}^{+}$supply would shift root uptake in favor of $\mathrm{Ca}^{2+}$ and $\mathrm{K}^{+}$at the expense of $\mathrm{Na}^{+}$thus protecting plant tissues from the adverse effects of high $\mathrm{NaCl}$ salinity. 


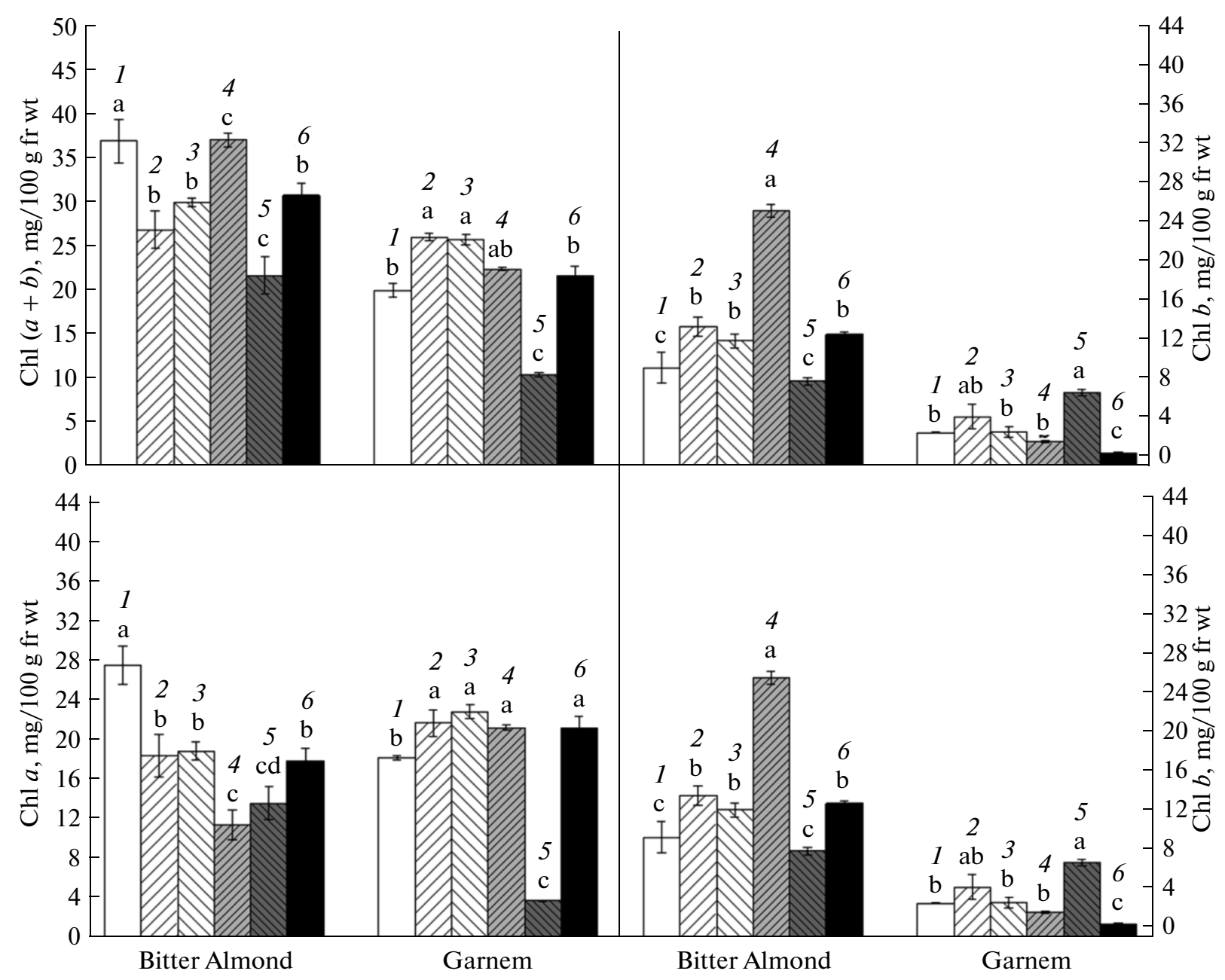

Fig. 4. Total chlorophyll (Chl $(a+b))$, chlorophyll $a(\mathrm{Chl} a)$, chlorophyll $b(\mathrm{Chl} b)$, as well as Chl $a / b$ ratio in the leaves of two almond rootstocks grown in a medium without $\mathrm{NaCl}$ (control), with $\mathrm{NaCl}$, or containing $\mathrm{KCl}$ or $\mathrm{CaCl}_{2}$ alone or together with $\mathrm{NaCl}$. 1-control; 2-8 mM CaCl $2 ; 3-10 \mathrm{mM} \mathrm{KCl} ; 4-75 \mathrm{mM} \mathrm{NaCl}+8 \mathrm{mM} \mathrm{CaCl} 2 ; 5-75 \mathrm{mM} \mathrm{NaCl}+10 \mathrm{mM} \mathrm{KCl} ; 6-$ $75 \mathrm{mM} \mathrm{NaCl}$. Each point represents the mean $( \pm \mathrm{SE})$ of four replicates, values marked by different letters are significantly different at $P<0.05$.

It was no surprise that all three measured growth parameters were reduced by the addition of $75 \mathrm{mM}$ $\mathrm{NaCl}$ to the growing medium for both rootstocks confirming previous reports indicating that almond tree is sensitive to salinity [13]. The electrical conductivity threshold in vegetative growth of almond trees was only $1.5 \mathrm{dS} / \mathrm{m}$, i.e., $15 \mathrm{mM}$ total salinity [13]. Hence, almond is considered a salt-sensitive glycophyte [7]. However, certain woody fruit crops differ in their ability to absorb and transport $\mathrm{Na}^{+}$and $\mathrm{Cl}^{-}$and have, therefore, different reactions to salt [14]. This appears to be the case of these two rootstocks. It was noticeable that Bitter Almond rootstock accumulated more $\mathrm{Na}^{+}$ in its leaves while Garnem accumulated more $\mathrm{Cl}^{-}$. The addition of $\mathrm{NaCl}$ reduced $\Psi_{\mathrm{w}}, g_{\mathrm{s}}$, and $E$ in both almond rootstocks (Fig. 3) as occurred in other species [2]. This is an expected response to the osmotic stress brought about by the medium high salt concentration.
The addition of $\mathrm{CaCl}_{2}$ or $\mathrm{KCl}$ to $\mathrm{BA}$ plants reduced their shoot growth, dry weight and leaf number. The basic nutrient solution was not concentrated enough to cause a significant reduction in vegetative growth. We think that Bitter Almond tree is sensitive to $\mathrm{Cl}^{-}$in the medium which concentration was further increased after addition of $\mathrm{CaCl}_{2}(8 \mathrm{mM})$ or $\mathrm{KCl}$ $(10 \mathrm{mM})$. Since $\mathrm{Cl}^{-}$level of $10 \mathrm{mM}$ in a soil extract is considered toxic to sensitive rootstocks, the reduction of growth was expected [14]. The growth reduction happened even though $A$ was not affected indicating a possible diversion of photo-assimilates from growth processes to proline and/or soluble sugars synthesis which helped, along with the reduction in water loss by transpiration, increased leaf $\Psi_{\mathrm{w}}$. The role of these osmolytes may have been the osmo-protection of proteins against $\mathrm{Cl}^{-}$toxicity rather than osmo-regulation [15]; in fact, leaf $\Psi_{\mathrm{w}}$ only slightly increased by the addition of $\mathrm{CaCl}_{2}$ and remained unchanged by $\mathrm{KCl}$. 


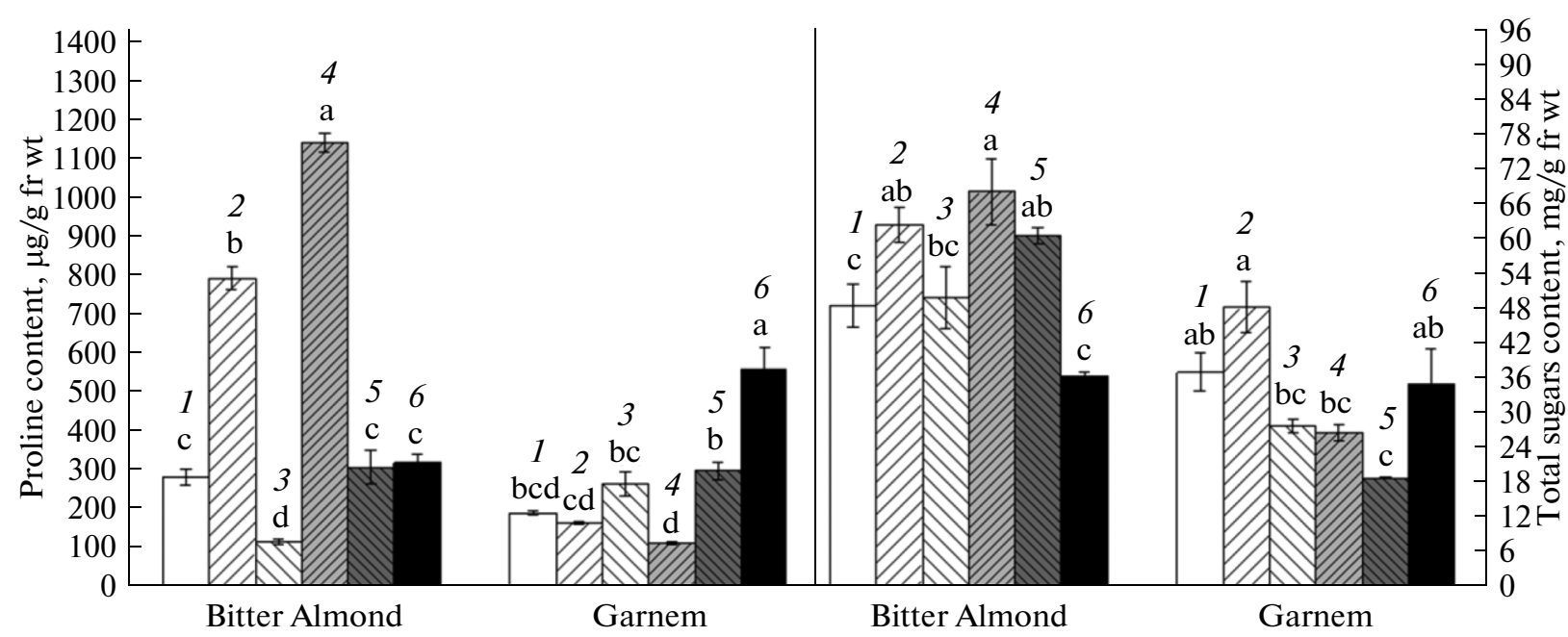

Fig. 5. Proline and total sugar content in the leaves of two almond rootstocks grown in a medium without $\mathrm{NaCl}$ (control), with $\mathrm{NaCl}$, or containing $\mathrm{KCl}$ or $\mathrm{CaCl}_{2}$ alone or together with $\mathrm{NaCl}$. 1 - control; $2-8 \mathrm{mM} \mathrm{CaCl}_{2} ; 3-10 \mathrm{mM} \mathrm{KCl} ; 4-75 \mathrm{mM} \mathrm{NaCl}+$ $8 \mathrm{mM} \mathrm{CaCl}_{2} ; 5-75 \mathrm{mM} \mathrm{NaCl}+10 \mathrm{mM} \mathrm{KCl} ; 6-75 \mathrm{mM} \mathrm{NaCl}$. Each point represents the mean $( \pm \mathrm{SE})$ of three replicates, values marked by different letters are significantly different at $P<0.05$.

When $\mathrm{CaCl}_{2}$ and $\mathrm{KCl}$ fertilizers were added along with $\mathrm{NaCl}$ to Bitter Almond trees, leaf $\mathrm{Ca}^{2+}$ and $\mathrm{K}^{+}$ contents increased while $\mathrm{Na}^{+}$and $\mathrm{Cl}^{-}$contents decreased leading to higher $\mathrm{Ca} / \mathrm{Na}$ and $\mathrm{K} / \mathrm{Na}$ ratios but shoot growth did not improve and even further declined compared to $\mathrm{NaCl}$-treated trees. It appears that the addition of salts further increased osmotic stress and more importantly aggravated $\mathrm{Cl}^{-}$toxicity as indicated by the accumulation of proline and soluble sugars in leaf tissues (osmotic adjustment and osmoprotection). Plant growth has suffered as a result of fertilization despite the improvement in ionic balances because photosynthesis was suppressed possibly due to the reduction in leaf area (there was some leaf abscission), content of Chl $a$, stomatal conductance and $A$.

The addition of $\mathrm{CaCl}_{2}$ to Bitter Almond plants improved their iWUE and $A$ relative to $g_{\mathrm{s}}$ (higher $A / g_{\mathrm{s}}$ ) possibly because of a more efficient carboxylation and reduced photorespiration due to partial closure of stomata [15].

The addition of $\mathrm{KCl}$ or $\mathrm{CaCl}_{2}$ to $\mathrm{NaCl}$-treated GN15 plants did not increase $A$ or shoot growth but it improved ionic balances as indicated by higher $\mathrm{Ca} / \mathrm{Na}$ and $\mathrm{K} / \mathrm{Na}$ ratios. Apart from the expected $\mathrm{Cl}^{-}$toxicity, the addition of these fertilizers caused additional water stress as indicated by the lower $\Psi_{\mathrm{w}}$. The leaf transpiration rate decreased due to lower $g_{\mathrm{s}}$. Our results showed that when $\mathrm{KCl}$ or $\mathrm{CaCl}_{2}$ were added alone (without $\mathrm{NaCl}$ ) they increased $g_{\mathrm{s}}$ and, to a lesser extent, $A$ and decreased $A / g_{\mathrm{s}}$ ratio. Therefore, the depressing effects of chloride salts on photosynthetic activity were predominantly due to non-stomatal limitations related to the toxic effect of $\mathrm{Na}^{+}$and $\mathrm{Cl}^{-}$. The Garnem plants showed a slight increase in water use efficiency (iWUE) as response to fertilization.
It is worth mentioning that Bitter Almond leaves did not display a significant degradation of total $\mathrm{Chl}$ content under $\mathrm{CaCl}_{2}$ treatments, but for the most part a clear conversion of Chl $a$ to the Chl $b$ (Fig. 4). It appeared, that $\mathrm{Ca}^{2+}$ boosted such conversion or, at least, stimulated de novo Chl $b$ biosynthesis. Similar trend was seen in GN15 plants too. The conversion of Chl $a$ to Chl $b$ appears now to be a part of general $\mathrm{Chl} a / b$ inter-conversion cycle which is thought to play a vital role in the formation and reorganization of the photosynthetic apparatus and which enables plants to adapt to various environmental conditions $[1,16]$.

Despite the improvement in nutritional balances after $\mathrm{Ca}^{2+}$ and $\mathrm{K}^{+}$fertilization, plant growth did not improve and even declined in the case of Bitter Almond because of the excessive concentration of $\mathrm{NaCl}$ in the growing medium for a salinity-sensitive species. Our results confirmed the sensitivity of these two rootstocks to both soil salinity and $\mathrm{Cl}^{-}$anions $[13,14]$.

The Bitter Almond, and to less extent GN15, are capable of osmotically adjust to high-salt environments. Indeed, the addition of $\mathrm{CaCl}_{2}$ to Bitter Almond plants was followed by a large accumulation of proline and soluble sugars in the leaves. It is likely, that the increase in cytosolic free $\mathrm{Ca}^{2+}$ in leaf cells acted at the transcriptional level to induce the expression of genes encoding for enzymes involved in proline biosynthesis [17]. Similarly, the higher $\mathrm{Ca}^{2+}$ content may stimulate amylase activity which degrades starch into sugars [17], and the increase in soluble sugars content can stimulate proline biosynthesis $[17,18]$.

In conclusion, almond tree is a salt-sensitive glycophyte. However, two rootstocks considered in this study differed in their response to the addition of chloride salts to the growing medium. The Garnem plants 
appeared to be slightly less sensitive to soil salinity than Bitter Almond plants, because they have the capacity to limit $\mathrm{Na}^{+}$uptake by roots and its translocation to the leaves [19]. The reduction in $A$ was mainly due to non-stomatal limitations in GN15, possibly due to the degradation of Chl $a$, unlike Bitter Almond plants for which the reduction was due to stomata closure. The improvement in ionic balances and water status of Bitter Almond trees in response to the addition of $\mathrm{KCl}$ or $\mathrm{CaCl}_{2}$ was apparently offset by a higher sensitivity to $\mathrm{Cl}^{-}$which caused some leaf abscission; therefore, non-chloride salts should be the preferred form of fertilizers for this rootstock. Both rootstocks were sensitive to soil salinity and cation supplements were of limited value in mitigating the effect of salt at high concentrations.

\section{ACKNOWLEDGMENTS}

This study was supported by the Islamic Bank for Development (IDB) through a grant given to T. T. to perform postdoctoral studies at Antwerp University. The authors are also grateful to the Technical Services of the University Miguel Hernandez, EPSO, Spain.

\section{REFERENCES}

1. Tilbrook, J. and Roy, S., Salinity tolerance, in Plant Abiotic Stress, Jenks, M.A. and Hasegawa, P.M., Eds., San Francisco, CA: Wiley, 2014, pp. 133-161.

2. Tounekti, T., Abreu, M.E., Khemira, H., and MunnéBosch, S., Canopy position determines the photoprotective demand and antioxidant protection of leaves in salt stressed Salvia officinalis L. plants, Environ. Exp. Bot., 2012, vol. 78, pp. 146-156.

3. Arshi, A., Abdin, M.Z., and Iqbal, M., Effects of $\mathrm{CaCl}_{2}$ on growth performance, photosynthetic efficiency and nitrogen assimilation of Cichorium intybus L. grown under $\mathrm{NaCl}$ stress, Acta Physiol. Plant., 2006, vol. 28, pp. 137-147.

4. Najafian, S., Rahemi, M., and Tavallali, V., Effect of salinity on tolerance of two bitter almond rootstock, Am.-Eurasian J. Agric. Environ. Sci., 2008, vol. 3, pp. 264-268.

5. Reighard, G., Ouellette, D., and Brock, K., Performance of new Prunus rootstocks for peach in South Carolina, Acta Hortic., 2008, vol. 772, pp. 237-240.

6. Zarrouk, O., Gogorcena, Y., Gómez-Aparisi, J., Betrán, A., and Moreno, M.A., Influence of almond $\times$ peach hybrids rootstocks on flower and leaf mineral concentration, yield and vigour of two peach cultivars, Sci. Hortic., 2005, vol. 106, pp. 502-514.

7. Zrig, A., Tounekti, T., Vadel, M., Ben Mohamed, H., Valero, D., Serrano, M., Chtara, C., and Khemira, H., Possible involvement of polyphenols and polyamines in salt tolerance of almond rootstocks, Plant Physiol. Biochem., 2011, vol. 49, pp. 1313-1322.

8. Condon, A., Richards, R., Rebetzke, G., and Farquhar, G., Improving intrinsic water-use efficiency and crop yield, Crop Sci., 2002, vol. 42, pp. 122-131.

9. Bates, L.S., Waldren, R.P., and Teare, I.D., Rapid determination of free proline for water stress studies, Plant Soil, 1973, vol. 39, pp. 205-207.

10. Biochemical Techniques: Theory and Practice, Robyt, J.F. and White, B.J., Eds., Monterey, CA: Brooks/Cole, 1987.

11. Arnon, D.I., Copper enzyme in isolated chloroplasts. Polyphenoloxidase in Beta vulgaris, Plant Physiol., 1949, vol. 24, pp. 1-15.

12. SAS/STAT ${ }^{\circledR}$ User's Guide: Statistics. Version 5506, Cary, NC: SAS Inst., 1996.

13. Tanji, K.K. and Kielen, N.C., Agricultural drainage water management in arid and semi-arid areas, in FAO Irrigation and Drainage, Paper 61, Rome: Food Agric. Org., 2002. http://www.fao.org/docrep/x5872e/ x5872e00.htm

14. Abrol, I.P., Yadav, J.S.P., and Massoud, F.I., Saltaffected soils and their management, FAO Soils Bull. 39, Rome: Food Agric. Org., 1988. http://fao.org/docrep/ x5871e/ x5871e00.htm

15. Plant Physiology, Salisbury, F.B. and Ross, C.W., Eds., Belmont, CA: Wadsworth, 1992.

16. Ito, H., Ohtsuka, T., and Tanaka, A., Conversion of chlorophyll $b$ to chlorophyll $a$ via 7-hydroxymethyl chlorophyll, J. Biol. Chem., 1996, vol. 271, pp. 14751479.

17. Jaleel, C.A., Beemarao, S., Ramalingam, S., and Rajaram, P., Soil salinity alters growth, chlorophyll content and secondary metabolite accumulation in Catharanthus roseus, Turk. J. Biol., 2008, vol. 32, pp. 79-83.

18. Noitsakis, B., Dimassi, K., and Therios, I., Effects of $\mathrm{NaCl}$ induced salinity on growth, chemical composition and water relations of two almond (Prunus amygdalus B.) cultivars and the hybrid GF677 (Prunus amygdalus $\times$ P. persica), Acta Hortic., 1997, vol. 449, pp. 641-648.

19. Greenway, H. and Munns, R., Mechanisms of salt tolerance in nonhalophytes, Annu. Rev. Plant Physiol., 1980, vol. 31, pp. 149-190. 